\title{
A Histological Study of Postnatal Development of Clavicle Articular Ends
}

\author{
Luis Fernando Calixto ${ }^{1 \rrbracket}$, Rodrigo Penagos ${ }^{1}$, Lina Jaramillo ${ }^{2}$, María Lucía Gutiérrez ${ }^{3,4}$, \\ Diego Garzón-Alvarado ${ }^{3}$
}

\begin{abstract}
The clavicle is the first bone to begin the process of ossification and the last one to complete it. Whilst histological studies of the clavicle have been focused mainly on embryonic events, our study focused on postnatal clavicle development. The objective of this study was to perform a qualitative description of the clavicle's epiphyseal growth to further shed light on the postnatal ossification process. Histological studies performed on clavicles obtained from cadavers confirmed medial and lateral extremities as true physes. Unlike the development of other long bones, no secondary ossification centre was present at the acromial end. Furthermore, appearance of the sternal end was observed after the age of 18 , as evidenced in clavicles from a 19-year old individual. The articular surface of the clavicle's acromial end was fibrocartilage. Thus far no histological studies have been performed before describing postnatal development of clavicular ends. Our data confirm the absence of an acromial secondary ossification centre, the late development of a secondary ossification centre at the sternal end, and the presence of fibrocartilage at the acromial end.
\end{abstract}

Keywords: acromial end; clavicle; fibrocartilage; sternal end

Edited by Juan Carlos Salcedo-Reyes $ه$

1. Department of Orthopaedic Surgery, School of Medicine, Universidad Nacional de Colombia, Bogotá, Colombia

2. Department of Pathology, School of Medicine, Universidad Nacional de Colombia, Bogotá, Colombia

3. Group of Mechanobiology of Organs and Biological Tissues (Mech+Biol_UN), Biomimetics Laboratory, Instituto de

Biotecnología, Universidad Nacional de Colombia, Bogotá, Colombia.

4. Institute of Inborn Errors of Metabolism, School of Science, Pontificia Universidad Javeriana, Bogotá, Colombia

Received: 06-12-2014 Accepted: 25-06-2015

Published on line: 18-09-2015

Citation: Calixto LF, Penagos R, Jaramillo L, Gutierrez ML \& GarzónAlvarado D (2015) A Histological Study of Postnatal Development of Clavicle Articular Ends. Universitas Scientiarum 20(3): 361-368 doi: 10.11144/Javeriana.SC20-3.ahso

Funding: N/A

Electronic supplementary material: N/A

\section{Introduction}

Bone formation can ensue by two different processes both derived from primitive mesenchymal tissue: intramembranous or endochondral ossification [1-3]. Intramembranous ossification occurs directly from primitive foetal mesenchyme differentiating into osteoblasts and forming bone. On the other hand, endochondral ossification requires first the formation of a cartilage mould, or anlagen, in a process known as chondrogenesis, followed by bone formation. These processes encompass a series of events starting with mesenchymal cell differentiation into chondrocytes. Cells then proliferate, and change their phenotype by increasing in volume as they hypertrophy. Subsequently a calcified matrix is synthesized by hypertrophic 
chondrocytes before they undergo apoptosis. Last, osteoblasts invade this mineralized scaffold for further mineral deposition and tissue maintenance [3-6].

The clavicle is the first bone to begin the process of ossification, and practically the last one to complete it [7-9]. For humans it has been reported to conclude at around the age of 25 [7,9]. Furthermore, it is the only long bone to ossify in an intramembranous manner. During embryonic development, ossification begins at the $5^{\text {th }}$ week with the appearance of two primary centres of ossification, a medial and a lateral centre in the shaft of the clavicle, which fuse at about the $6^{\text {th }}$ week [10-11]. After fusion of the two primary ossification centres, secondary cartilage develops directly from mesenchymal tissue at the sternal and acromial ends. These cartilaginous masses allow growth by endochondral ossification. The longitudinal growth is sustained mainly at the expense of medial cartilage mass at the sternal end of the clavicle by endochondral ossification, and the increase in diameter is given by intramembranous ossification of the periosteum $[8,11-13]$.

Based on their histological organization, each secondary cartilage end displays the configuration of a physis with its five areas of histological differentiation: reserve zone I, proliferation II, hypertrophy III, calcification IV, and vascular invasion V [14]. From these secondary centres longitudinal growth occurs, different from the pattern displayed by all other major long bones of the limb [7-9]. For long bones there is a real early physis between the secondary ossification centre of epiphyseal ossification and the diaphyseal ossification area [14]. [8]. Furthermore, the clavicle's ossification process is of slow maturation so the final epiphysis fuses at the age of approximately 19 years [10]. Thus, the clavicle is considered the first bone to ossify and the last epiphysis to fuse.

The aim of this work was to carry out a histological description of the growth and development of the medial and lateral ends of the clavicle from birth to skeletal maturity. The masses of the secondary cartilage in the acromial and sternal ends were established histologically as a true physis, where longitudinal growth occurred. The main finding of this work was the absence of a secondary ossification centre at the acromial end, and a late appearance at the sternal end.
In the sternal end we found an ossification centre at the age of 19 years, when longitudinal growth was finalizing. The articular surface of the acromial end of the clavicle consisted of fibrocartilage, unlike the usual hyaline cartilage of long bones.

\section{Materials and Methods}

A histological descriptive study was developed from 64 anatomical blocks of clavicles obtained from cadavers, whose ages ranged from new-borns to a 19-year old adult, after signed informed consent by the parent or guardian. This study was carried out at the paediatric Hospital de la Misericordia in Bogota, Colombia after approval by the Ethics Committee, and under strict guidance provided by the Colombian Department of Social Protection for the management of anatomical parts.

Inclusion criteria included non-fractured clavicles from males or females who died of medical and not traumatic conditions to assure physis integrity for histological interpretation. Furthermore, donors did not die from any pathology associated with osteochondral or joint related disease or metabolic disorders. Samples from all clavicles were obtained from individuals without lesions at the scapular level. Samples were divided according to age group (Table 1). We present representative data from an 8-day newborn, a two-year old, six-year old, ten-year old, and 19-year old individuals. Thirty two acromial and 32 sternal ends were examined respectively.

Table 1. Classification of samples according to age.

\begin{tabular}{lccc}
\hline & $\begin{array}{c}\text { Acromial end } \\
\text { No. of samples }\end{array}$ & $\begin{array}{c}\text { Sternal end } \\
\text { No. of samples }\end{array}$ & Total \\
\hline Newborns - 1 month & 8 & 8 & 16 \\
1 - 24 months & 6 & 6 & 12 \\
2 - 5 years & 6 & 6 & 12 \\
6 - 12 years & 6 & 6 & 12 \\
13 - 19 years & 6 & 6 & 12 \\
Total & 32 & 32 & 64 \\
\hline
\end{tabular}

Dissections were performed after removing acromioclavicular and sternoclavicular joints. Samples were placed in two different blocks as follows: The 
first block included $1 \mathrm{~cm}$ of ossified medial clavicle, articular cartilage, joint, sternum's articular cartilage, and $1 \mathrm{~cm}$ of sternum. The second block was dissected $1 \mathrm{~cm}$ from the lateral calcified clavicle including acromioclavicular ligaments, coracoclavicular ligament, and $1 \mathrm{~cm}$ of acromion (Figure 1). Blocks were fixed in $10 \%$ buffered formalin, followed by decalcification in sodium citrate and formic acid solution. Axial and coronal cuts of the acromioclavicular joint and sternoclavicular joint were performed. Samples were embedded in paraffin and $5-\mu \mathrm{m}$ sections were performed, followed by hematoxylin and eosin (H\&E) staining [15]. Microscopic analysis was performed from representative micrographs by two blinded observers and all results herein described derive from these observations.

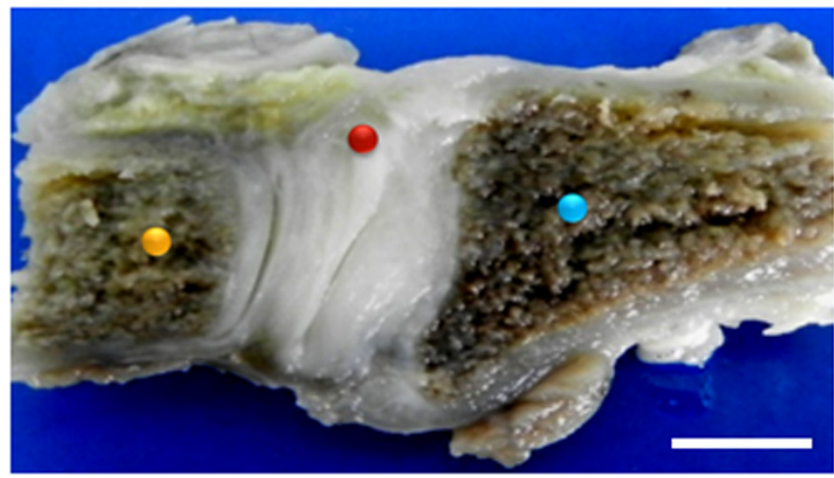

Fig. 1. Acromioclavicular joint of a 5-year old boy. Coronal section of the left joint depicting lateral clavicle (blue), articular menisc (red), and ossified acromial end (yellow). There were no secondary ossification centres. Scale bar $15 \mathrm{~mm}$.

\section{Results}

This study provides a detailed histological evaluation of postnatal anatomy of the human clavicle, mainly the ossification centres of its two ends in a unique collection of samples from new-born babies to individuals of age 19 (Figure 2).

\section{Acromioclavicular joint}

Histological studies of new-borns to one-month old babies evidenced articular cartilage chondrocytes as an immature physis, with disorganized chondrocytes not forming orderly columns. New-born babies to one- month old babies' clavicle presented large
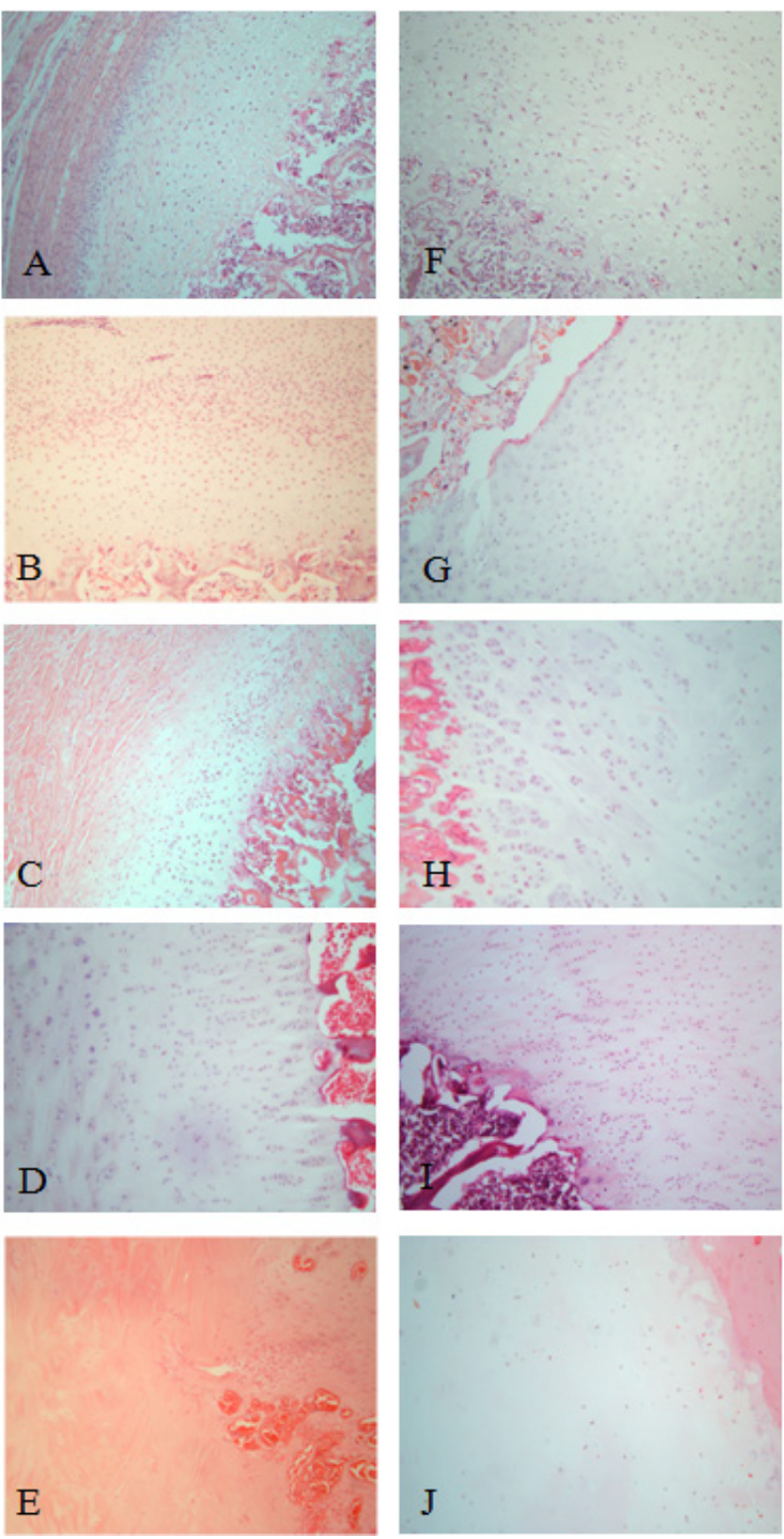

Fig. 2. Acromial and sternal developmental ages. Postnatal anatomy of the human clavicle for acromial ends (A - E) and sternal ends $(\mathbf{F}-\mathbf{J})$. Representative samples from different ages: eight-day new-born (A, F), two-year old (B, G), six-year old $(\mathbf{C}, \mathbf{H})$, ten-year old $(\mathbf{D}, \mathbf{I})$, and 19-year old $(\mathbf{E}, \mathbf{J})$. 10X magnification.

chondrocytes in lacunae in a disorganized manner (Figure 3). Following postnatal development, in onemonth old babies to two-year old toddlers, the articular cartilage acquired greater cellularity, as determined by visual assessment. Cells began to exhibit a distinct polarization within a plane, known as planar cell polarity (PCP) organization towards the acromial end 


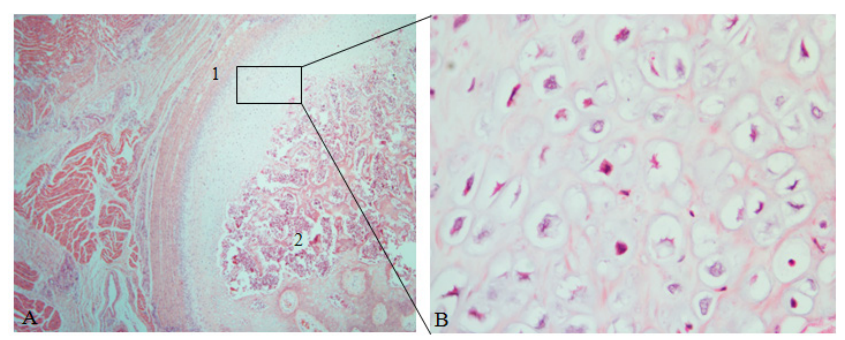

Fig. 3. Acromioclavicular joint of an 8-day old new-born. Articular cartilage depicting large chondrocytes encased in large lacunae in a disorganized manner. H\&E stain. (A) 1. Articular end. 2. Diaphysis. 4X magnification. (B) 40X magnification.

nearest to the articulation (Figure 4, 1). However, some disorganization was observed, particularly in the end nearest to the diaphysis (Figure 4, 2). Lacunae decreased in size compared to an eight-day old newborn, adjusting more to the size of the chondrocyte.

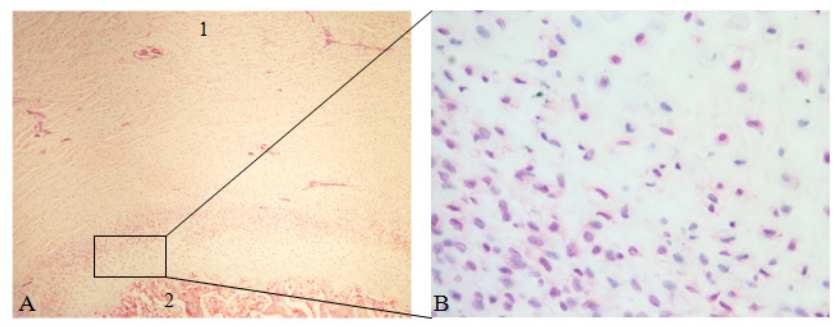

Fig. 4. Articular cartilage acromial end of a 2-year old toddler. Articular cartilage increased in cellularity, yet somewhat disorganized. Lacunae decreased in size, adjusting to the chondrocyte. H\&E stain. (A) 1. Acromial articular end. 2. Diaphysis. $4 \mathrm{X}$ magnification. (B) 40X magnification.

For clavicles of children between the ages of two to six years old we observed the beginning of column formation. The cartilage's lateral end displayed a maturing physis with chondrocytes organized in short columns containing three to five cells. In addition, chondrocytes progressively assumed a less rounded morphology (Figure 5). For clavicles from children between the ages of five to six years old there was a clear decrease in physis cellularity in zones III, IV and $\mathrm{V}$ (hypertrophic to vascular invasion zones compared to resting and proliferating zones). In these zones chondrocytes appeared in large lacunae and well defined with a clear organization in groups or columns separated by an abundant chondroid matrix.

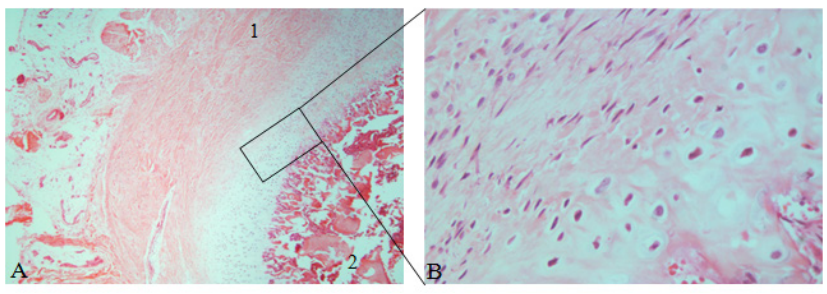

Fig. 5. Articular cartilage acromial end of a 6-year old child. Articular cartilage. Starting to display column arrangement with groups of three to five cells. H\&E stain.

(A) 1. Acromial articular end. 2. Diaphysis. 4X magnification.

(B) $40 \mathrm{X}$ magnification.

Up to the age of nine, chondrocytes started to organize in columns. Nuclei were oval or round, and lacunae size was proportional to chondrocyte size. True column organization was observed between the ages of 10 and 14. These long columns contained nuclei that acquired a more flattened appearance. Correspondingly lacunae were not very prominent, surrounded by abundant amorphous hyaline cartilage (Figure 6).

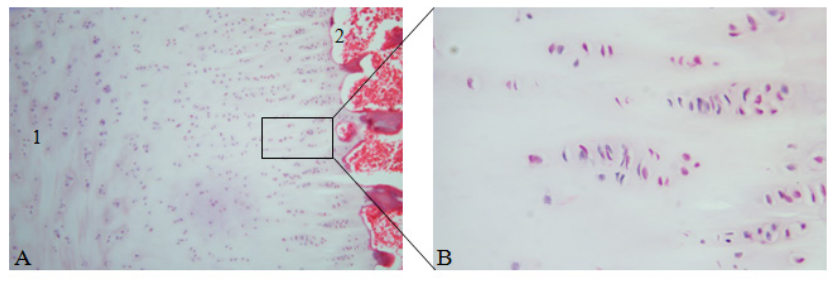

Fig. 6. Articular cartilage acromial end of a 10 -year old child. True 'stack of coin' formation. H\&E stain. (A) 1. Acromial articular end. 2. Diaphysis. 10X magnification. (B) $40 \mathrm{X}$ magnification.

For teenagers' clavicles, between the ages of 12 and 18 years, articular cartilage had a decreased cellularity compared with previous age groups with an increasing fibrous matrix with what seem to be apoptotic cells and a clear ossification zone. At the acromial end there was no presence of secondary ossification centre (data not shown).

For the 19-year old young adult, articular cartilage had diminished cellularity compared with the previous age group. We evidenced reduced chondrocyte nuclei, with hardly any lacunae present, surrounded by generous cartilaginous matrix with fibers (Figure 7). We did not observe on this sample a secondary 
ossification centre; instead we observed cells with a spindle shape surrounded by fibrocartilage.
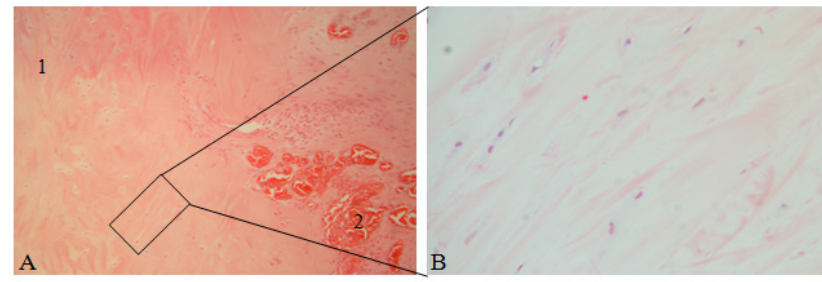

Fig. 7. Articular cartilage acromial end of a 19-year old adult. Scarce cellularity. Chondrocytes with small elongated nuclei. Lacunae barely present. H\&E stain. (A) 1. Acromial articular end. 2. Diaphysis. 10X magnification. (B) $40 \mathrm{X}$ magnification.

In sum, results from the acromial end evidenced chondrocytes at the epiphysis gaining organization with increasing age. Cell density was high in new-born to four-year old children. It diminished for children between ages of five to nine. No secondary centres of ossification were observed. In the young adult fibrocartilage was present at the acromial end.

\section{Sternoclavicular joint}

Results obtained from the new-born clavicle's sternal or medial end evidenced an immature physis, histologically disorganized without column formation, comparable to the results obtained from the acromial end (Figure 8). Clavicles obtained from one-month

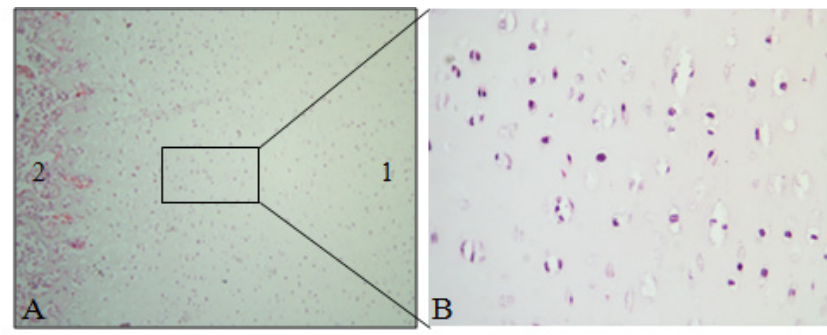

Fig. 8. Sterno-clavicular joint of an 8-day old new-born. Histologically disorganized, with an immature physis without column formation. Large chondrocytes with round nuclei and not well defined lacunae. H\&E stain. (A) 1. Sternal articular end. 2. Diaphysis. 4X magnification. (B) $40 \mathrm{X}$ magnification.

old babies to two-year old toddlers initiated lacunae formation. We observed occasional chondrocyte cluster formation (Figure 9).

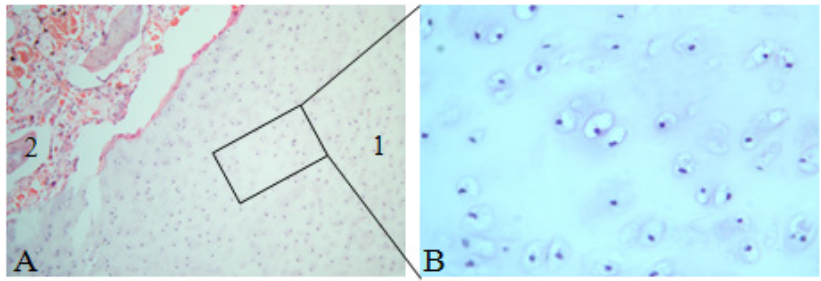

Fig. 9. Sterno-clavicular joint of a 2-year old toddler. Chondrocytes with elongated or round nuclei encased in prominent lacunae. Occasional cell clusters are present. H\&E stain. (A) 1. Sternal articular end. 2. Diaphysis. 10X magnification. (B) $40 \mathrm{X}$ magnification.

In the age group between two- to six-year old children there was the classical 'stack of coins' organization (Figure 10). In contrast to the acromioclavicular joint, there were fewer columns and higher cell densities in zones III through V of the physis (hypertrophic to vascular invasion zones).

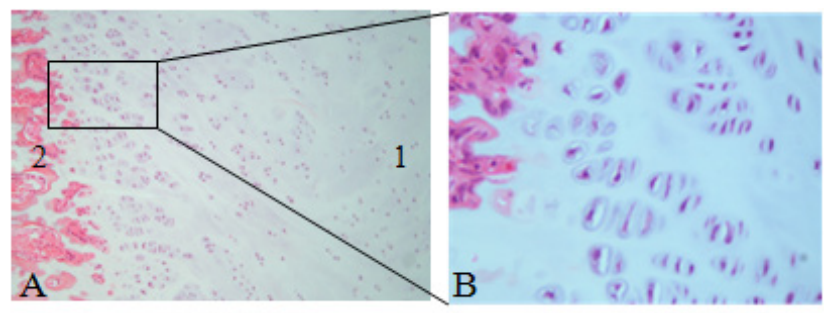

Fig. 10. Sterno-clavicular joint of a 6-year old child. Evident formation of a 'stack of coins' column organization. Nuclei progressively more flattened with smaller lacunae. H\&E. (A) 1. Sternal articular end. 2. Diaphysis. 10X magnification. (B) $40 \mathrm{X}$ magnification.

Between the ages of 6 and 12-year old children, we confirmed a physis comprising defined columns with flattened cells; however, there was decreased cell density in the secondary articular cartilage (Figure 11).
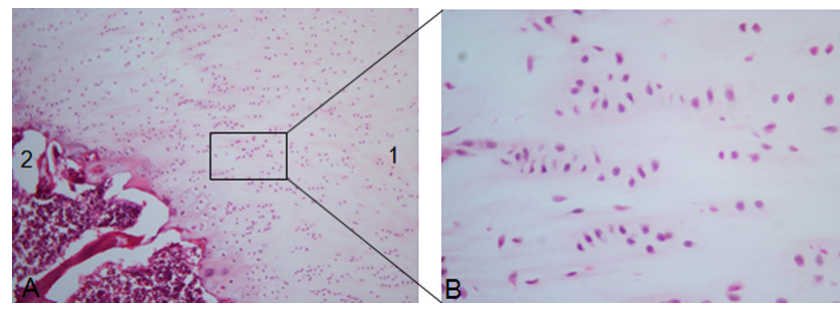

Fig. 11. Sterno-clavicular joint of a 10-year old child. 'Stack of coins' column organization. Cells are smaller compared to a six-year old child. H\&E. (A) 1. Sternal articular end. 2. Diaphysis. 10X magnification. (B) $40 \mathrm{X}$ magnification. 
Finally, in the adult specimen (clavicles obtained from a 19-year old man) we observed a decrease in cell number. Furthermore, this end had articular hyaline cartilage with a thin perichondrium with the appearance of a secondary ossification centre (Figure 12). Emergence of the sternal end occurred relatively late in life, at the age of 19, when growth was finalizing.
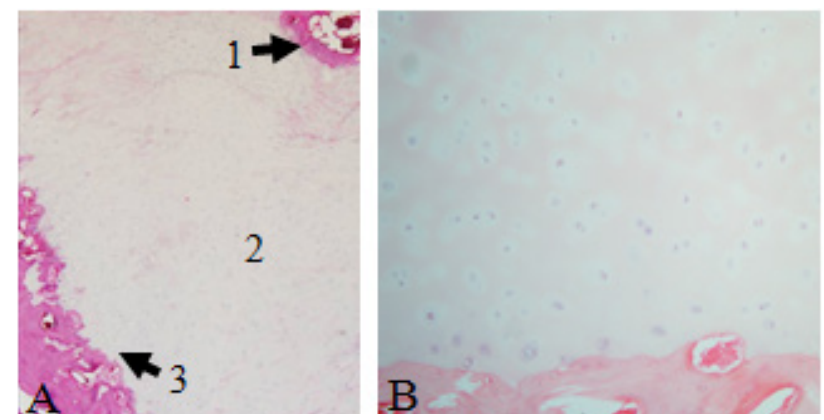

Fig. 12. Adult sterno-clavicular joint. Adult sternal end of the clavicle of a 19-year old man (A) Secondary centre of ossification (arrow 1), hyaline cartilage with scarce cellularity (2), clavicle metaphyseal end (arrow 3). H\&E. 10 X magnification. (B) Sternoclavicular end with abundant hyaline cartilage $40 \mathrm{X}$ magnification.

Overall, there were distinct histological differences between the acromial and sternal secondary cartilages regarding cellularity, secondary ossification centre, and kind of cartilage. For the lateral end we observed greater cell density and no secondary centre of ossification with fibrocartilage at the acromial articular end. The sternal end presented a secondary centre of ossification in a 19-year old male in addition to hyaline cartilage.

\section{Discussion}

This work describes histological changes during the growth and development of the medial and lateral ends of the clavicle from birth to skeletal maturity. This important and unique study provides new detailed postnatal developmental histological anatomy description of the ossification centres of the acromial and sternal ends of the human clavicle, and its differences from regular long bone endochondral ossification.

Histological studies of the development of the clavicle have focused on embryonic stages $[7,8,11]$. To date, to the best of our knowledge, no research has addressed the clavicle's postnatal development with histological studies describing both acromial and sternal ends. The few studies reporting the clavicle's postnatal development in the literature are imaging studies without histological correlation $[12,16]$. The main findings of this study were: the epiphysis behaved as a true physis, no secondary centres of ossification were found before the age of 18 , and fibrocartilage was observed on the acromial end.

It has been reported in the literature that the clavicle grows in length differently from long bones [7-9]. From our histological studies we evidenced that the clavicle's epiphyseal growth behaves in the same way as the development of a true physis in a long bone. We observed all areas described in the literature: reserve zone I, proliferation II, hypertrophy III, calcification IV, and vascular invasion V [5, 17-19]. Chondrocytes at the acromial end increased their organization in orderly columns with increasing age. For the newborn stage until the first month the physis was histologically disorganized with lack of a hypertrophic zone. Changes in organization were evidenced with modifications in cell configuration, finally reaching a true physis by the age of six.

In agreement with the literature we did not observe a secondary centre of ossification at the acromial end [20, 21]; therefore, we cannot refer to fusion of secondary nucleus at this end. On the other hand, we observed a secondary centre of ossification at the sternal end in a 19-year old male. This is in contrast to reports in the literature describing closure of sternal physis from the ages of 19 to 25 [22]. Additionally, Odgen et al. have reported the development of the secondary centre of ossification in the beginning of adolescence (13-14 years), with contribution of overall length up to $80 \%$ at the expense of the sternal's end endochondral ossification [12]. Since we only found presence of this secondary centre at the beginning of adulthood in an adult male, we suggest this mechanism contributes little to the clavicle's longitudinal length. Furthermore, future studies with additional skeletal elements in adult individuals ranging from the ages of 18 to 25 will definitely confirm a secondary ossification centre at these ages.

Comparing sternal and acromial ends we confirmed differences between both ends. The acromial end had 
a denser cellularity. Furthermore, we did not observe a secondary ossification centre. In contrast, the sternal end presented a secondary ossification centre in early adulthood with hyaline cartilage present in this articulation.

In sum, this detailed histological study provides complementary information on the clavicle's postnatal evolution, presenting in a descriptive manner the histological development of the physes from new-born to early adulthood. As a histological study in cadavers in the forensic field, it allows a clear confirmation of the estimated forensic age of individuals by radiological findings [16, 22]. This work is useful to researchers in biological sciences, medical students, and physicians in the clinic.

\section{Acknowledgements}

This work did not receive any kind of funding.

\section{Conflicts of interest}

We declare no conflict of interest regarding the results published in this article.

\section{References}

1. Kronenberg, H.M., Developmental regulation of the growth plate. Nature, 2003. 423(6937): p. 332-6.

2. Karsenty, G., H.M. Kronenberg, and C. Settembre, Genetic control of bone formation. Annu Rev Cell Dev Biol, 2009. 25: p. 629-48.

3. Geneser, F., Histology over biomolecular basis, Munksgaards, Editor. 1999.

4. Stevens, S.S., G.S. Beaupre, and D.R. Carter, Computer model of endochondral growth and ossification in long bones: biological and mechanobiological influences. J Orthop Res, 1999. 17(5): p. 646-53.

5. Ballock, R.T. and R.J. O'Keefe, The biology of the growth plate. J Bone Joint Surg Am, 2003. 85-A(4): p. 715-26.

6. Zuscik, M.J., et al., Regulation of chondrogenesis and chondrocyte differentiation by stress. J Clin Invest, 2008. 118(2): p. 42938.

7. Ogata, S. and H.K. Uhthoff, The early development and ossification of the buman clavicle-an embryologic study. Acta Orthop Scand, 1990. 61(4): p. 330-4.

8. Gardner, E., The embryology of the clavicle. Clin Orthop Relat Res, 1968. 58: p. 9-16.
9. Montenegro, M., M. Rojas, and S. Domínguez, Comparative Osteogenesis of the clavicle secondary cartilages and epiphyseal cartilages of long bones. Int. J. Morphol, 2004. 22(3): p. 201206.

10. Scheuer, L. and S. Black, The clavicle, in The Jwvenile Skeleton, Elsevier, Editor. 2004 Elsevier. p. 247 - 252.

11. Fawcett, The Development and Ossification of the Human Clavicle. J Anat Physiol, 1913. 47(Pt 2): p. 225-34.

12. Ogden, J.A., G.J. Conlogue, and M.L. Bronson, Radiology of postnatal skeletal development. III. The clavicle. Skeletal Radiol, 1979. 4(4): p. 196-203.

13. Glenister, T.W., An embryological view of cartilage. J Anat, 1976. 122(Pt 2): p. 323-30.

14. Brighton, C.T., The growth plate. Orthop Clin North Am, 1984. 15(4): p. 571-95.

15. Fischer, A.H., et al., Hematoxylin and eosin staining of tissue and cell sections. CSH Protoc, 2008. 2008: p. pdb prot4986.

16. Schmeling, A., et al., Studies on the time frame for ossification of the medial clavicular epiphyseal cartilage in conventional radiography. Int J Legal Med, 2004. 118(1): p. 5-8.

17. de Crombrugghe, B., et al., Transcriptional mechanisms of chondrocyte differentiation. Matrix Biol, 2000. 19(5): p. 38994.

18. Vortkamp, A., et al., Regulation of rate of cartilage differentiation by Indian hedgehog and PTH-related protein. Science, 1996. 273(5275): p. 613-22.

19. Phornphutkul, C. and P.A. Gruppuso, Disorders of the growth plate. Curr Opin Endocrinol Diabetes Obes, 2009. 16(6): p. 430-4.

20. Todd, T. and J. D'Errico, The clavicular epiphyses. American Journal of Anatomy, 1928. 41(1): p. 25 - 50.

21. Richards, D.P. and A. Howard, Distal clavicle fracture mimicking type IV acromioclavicular joint injury in the skeletally immature atblete. Clin J Sport Med, 2001. 11(1): p. 57-9.

22. Garamendi, P.M., et al., Forensic age estimation on digital X-ray images: Medial epiphyses of the clavicle and first rib ossification in relation to chronological age. J Forensic Sci. 56 Suppl 1: p. S3-12. 
Estudio histológico del desarrollo posnatal de los extremos articulares de la clavícula

Resumen. La clavícula es el primer hueso que comienza el proceso de osificación y el último en completarlo. Mientras los estudios histológicos de la clavícula se han enfocado principalmente en los eventos embrionarios, nuestro estudio se enfoca en su desarrollo posnatal. El objetivo de este estudio fue llevar a cabo una descripción cualitativa del crecimiento epifisario de la clavícula, que pueda arrojar luz sobre el proceso de osificación posnatal. Los estudios histológicos llevados a cabo en clavículas procedentes de cadáveres confirman que las extremidades mediales y laterales son verdaderas fisis. A diferencia del desarrollo de otros huesos largos, no se encuentra otro centro de osificación secundaria en la extremidad acromial. Por otra parte, la aparición de la extremidad esternal ocurre a la edad de 18 años, como se evidenció en clavículas del individuo de 19 años de edad. La superficie articular del extremo acromial de la clavícula era fibrocartílago. No se han realizado hasta ahora estudios histológicos que describan el crecimiento posnatal de las extremidades claviculares. Nuestros datos confirman la ausencia de un centro de osificación secundaria acromial, el desarrollo tardío de un centro de osificación secundaria en la extremidad esternal y la presencia de fibrocartílago en la extremidad acromial.

Palabras clave: extremidad acromial; clavícula; fibrocartílago; extremidad esternal
Um estudo histológico do desenvolvimento pós-natal das extremidades articulares da clavícula

Resumo. A clavícula é o primeiro osso a iniciar o processo de ossificação e o último em completar. Enquanto estudos histológicos da clavícula têm sido focados principalmente em eventos embrionários, nosso estudo enfoca no desenvolvimento pós-natal da clavícula. O objetivo de esse estudo foi realizar uma descrição qualitativa do crescimento epifisário da clavícula para aclarar o processo de ossificação pós-natal. Estudos histológicos realizados em clavículas obtidas de cadáveres confirmaram as extremidades mediais e laterais como fises reais. Diferente do desenvolvimento de outros ossos longos, nenhum centro de ossificação secundário estava presente na extremidade acromial. Além disso, o aparecimento da extremidade esternal foi observado após os 18 anos, sendo evidenciado em clavículas de indivíduos de 19 anos. A superfície articular da extremidade acromial da clavícula era fibrocartilaginosa. Nenhum estudo histológico havia sido realizado previamente descrevendo o desenvolvimento pós-natal das extremidades claviculares. Nossos dados confirmam a ausência de um centro de ossificação secundária acromial, o desenvolvimento tardio de centro de ossificação secundário na extremidade esternal, e a presença de fibrocartilagem na extremidade acromial.

Palavras-chave: Extremidade acromial; clavícula; fibrocartilagem; extremidade esternal 